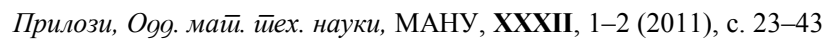
Contributions, Sec. Math. Tech. Sci., MANU, XXXII, 1-2 (2011), p. 23-43

ISSN 0351-3246

UDC: $547.574: 543.422 .3-76$

\title{
DETERMINATION OF THE DISSOCIATION CONSTANTS OF SOME $p$-SUBSTITUTED AROMATIC HYDRAZONES
}

\author{
Mirjana Jankulovska ${ }^{1}$, Ilinka Spirevska ${ }^{1}$, Katica Cholancheska Ragjenovikj ${ }^{2}$
}

A b s t r a c t: The acid-base behavior of five $p$-substituted aromatic hydrazones has been studied, using UV spectrophotometric method. The influence of the acidity of the medium on the absorption spectra is followed in aqueous sodium hydroxide solutions in $\mathrm{pH}$ region from 7 to 14 . The measurements are performed at room temperature, and at ionic strength of $0.1,0.25$ and $0.5 \mathrm{~mol} \mathrm{dm}{ }^{-3}$. A batochromic shift of the absorption band that appears in neutral media is observed, when $\mathrm{pH}$ is up to 7 . It suggests that the dissociation process of the amide and hydroxyl group takes place. Deprotonation enthalpies and total energy values are calculated by using the semiempirical methods AM1 and PM3. Using the changes in the UV spectra with $\mathrm{pH}$ of the solution, the determination of dissociation constants, $\mathrm{p} K_{\mathrm{BH}}$, at three different ionic strengths, as well as, the thermodynamic dissociation constants at zero ionic strength, is performed. In order to obtain more precise results, the calculations are made from the absorbance values at four selected wavelengths. Furthermore, the $\mathrm{p} K_{\mathrm{BH}}$ values were determined graphically from the intercept of the dependence of $\log I$ on $\mathrm{pH}$. The results showed that the numerically calculated $\mathrm{p} K_{\mathrm{BH}}$ values are identical to those graphically obtained.

Key words: $p$-substituted aromatic hydrazones, dissociation, UV spectrophotometry, dissociation constants, thermodynamic dissociation constants, semiempirical methods AM1 and PM3 


\section{INTRODUCTION}

The importance of hydrazones and their derivatives arises from their wide use in many scientific fields. This use is due to presence of azometine group $(-\mathrm{NH}-\mathrm{N}=\mathrm{CH}-)$ in their molecule. Some hydrazones are used as quantitative analytical reagents in colorimetric, fluorimetric $[1,2]$, and especially in spectrophotometric determinations of metal ions, because they act as multidentate ligands with transition metal ions forming colored chelates [3]. Hydrazone complexes have been of interest for many authors from aspect of coordination chemistry [4]. The knowledge of behavior of hydrazones in solution with different acidity is important in order to achieve higher sensitivity and selectivity for the metal determination [5].

In addition, hydrazones are useful as preferred derivatives for the identification and characterization of carbonyl compounds, which can be regenerated from phenyl hydrazones using the method well known from the literature $[6,7]$. Hydrazones have also been used for different purposes such as: herbicides, insecticides, nematocides, rodenticides, plant growth regulators, sterilants for houseflies, among other applications [8]. Furthermore, the hydrazones are important for their use as plasticizers and stabilizers for polymers, polymerization initiators and antioxidants $[9,10]$. On the other hand, tautomerism and isomerism phenomena for these compounds are of particular chemical and theoretical interest. The hydrazo tautomer exists in neutral solutions whereas the azo tautomer exists in strong acidic or alkaline solutions [11].

However, the most valuable property of hydrazones is their great physiological activity. It is well known that the hydrazone group provides a wide range of applications in biological and pharmaceutical fields. Therefore, a number of hydrazone derivatives have been claimed to possess interesting anticonvulsant, antidepressant, analgesic, antiinflammatory, antiplatelet, antimalarial, antimicrobial, antitumoral and antiviral activities [12-19]. Furthermore, hydrazones can display antitubercular effects based on their tendency to form stable metal chelates with transition metal ions [20], which catalyze the physiological processes [21].

The biological activity of the organic compounds like investigated ones, depends on the $\mathrm{pH}$ values of the media, thus the behavior of these compounds in acidic and basic media is very significant. Because of that the behaviour of the investigated hydrazones was previously followed in perchloric acid medium [22]. On the other hand, the dissociation constants are important parameters for understanding and quantifying chemical phenomena such as re- 
action rates, biological activity, biological uptake and biological transport [23]. Proton transfer reactions are very important in chemistry and knowledge of proton affinities of bases and deprotonation enthalpies (DPE) of acids is therefore essential. The results for the deprotonation enthalpies obtained using the experimental techniques are limited to the gas phase and are available only for a limited number of ions and molecules. Therefore, the calculations of the DPE theoretically, using semiempirical methods, could be carried out more quickly and they are not limited by the physical properties of the molecules.

In this study, using the UV spectrophotometry method, we followed the behavior in basic media of five $p$-substituted aromatic hydrazones. Our aim was to determine the dissociation constants, as well as, thermodynamic dissociation constants of these compounds. In addition, we calculated total energy and deprotonation enthalpy values in order to determine the site of dissociation of the investigated hydrazones.

The structure of the hydrazones under study is presented in the Table 1.

Ta b le 1

Nomenclature and formulas of the studied hydrazones

\begin{tabular}{cccc} 
& & & \\
& & & \\
Compound & $\mathrm{R}$ & Name & \\
\hline $\mathbf{H}_{\mathbf{1}}$ & $-\mathrm{H}$ & $N$-benzaldehydebenzoilhydrazone & $\mathrm{C}_{14} \mathrm{H}_{12} \mathrm{ON}_{2}$ \\
$\mathbf{H}_{2}$ & $-\mathrm{CH}_{3}$ & $N$-benzaldehyde- $p$-methylbenzoilhydrazone & $\mathrm{C}_{15} \mathrm{H}_{14} \mathrm{~N}_{2} \mathrm{O}$ \\
$\mathbf{H}_{3}$ & $-\mathrm{OCH}_{3}$ & $N$-benzaldehyde- $p$-methoxybenzoilhydrazone & $\mathrm{C}_{15} \mathrm{H}_{14} \mathrm{O}_{2} \mathrm{~N}_{2}$ \\
$\mathbf{H}_{\mathbf{4}}$ & $-\mathrm{Cl}$ & $N$-benzaldehyde- $p$-chlorobenzoilhydrazone & $\mathrm{C}_{14} \mathrm{H}_{11} \mathrm{ON}_{2} \mathrm{Cl}$ \\
$\mathbf{H}_{5}$ & $-\mathrm{OH}$ & $N$-benzaldehyde- $p$-hydroxybenzoilhydrazone & $\mathrm{C}_{14} \mathrm{H}_{12} \mathrm{O}_{2} \mathrm{~N}_{2}$ \\
\hline
\end{tabular}

The investigated hydrazones are synthesized in our laboratory and structurally characterized by UV spectroscopy, infrared spectroscopy (IR), nuclear magnetic resonance $\left({ }^{1} \mathrm{H}\right.$ NMR and ${ }^{13} \mathrm{C}$ NMR), as well as, by elemental analysis (the results are in preparation for publication).

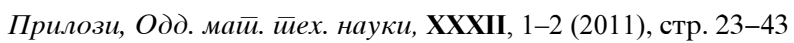




\section{EXPERIMENTAL}

\section{Preparation of a stock and test solutions}

A stock solution of the hydrazones is prepared by dissolving about 60 $\mathrm{mg}$ of the compound in $96 \%$ ethanol in a volumetric flask of $250 \mathrm{~cm}^{3}$. The volume of $0.75 \mathrm{~cm}^{3}$ of this solution is transferred into $25 \mathrm{~cm}^{3}$ volumetric flask, and after adding appropriate volume of $\mathrm{NaOH}\left(c=0.5 \mathrm{~mol} \mathrm{dm}^{-3}\right)$ and $\mathrm{NaClO}_{4}(c=$ $1 \mathrm{~mol} \mathrm{dm}^{-3}$ ) the flask is diluted up to the mark with deionized water. The degree of dilution of the stock solutions is chosen to obtain concentration of the hydrazones in the test solution of about $3 \cdot 10^{-5} \mathrm{~mol} \mathrm{dm}^{-3}$ i.e. the absorbances to have a value between 0.1 and 1 at the studied wavelengths. The $\mathrm{pH}$ of the test solutions is adjusted with $\mathrm{NaOH}$, while the ionic strength is maintained constant $\left(0.1,0.25\right.$ and $\left.0.5 \mathrm{~mol} \mathrm{dm}^{-3}\right)$ using the solution of $\mathrm{NaClO}_{4}$. The UV spectra are taken immediately after preparation of the test solutions, at room temperature. After that the $\mathrm{pH}$ of each test solution is measured. The solution which does not contain the investigated hydrazone, but has the same composition as tested one, is used as a blank. The stock solutions were stable a long period of time under ordinary conditions, while the stability of the working solution was satisfactory only 24 hours of time.

\section{Equipment and chemicals}

The aromatic hydrazones are purified by twice recrystalization from ethanol or diluted ethanol. The purity of the hydrazones is tested by measuring of melting point, as well as, by the data of elemental analysis. The other chemicals $\left(\mathrm{NaOH}, \mathrm{NaClO}_{4}\right.$ and ethanol) were of analytical grade p.a. (Alkaloid), and they are used without further purification.

A digital $\mathrm{pH}$ meter with glass electrode ( $\mathrm{pH}$ range from 1 to 14 ) is used for measurements of the $\mathrm{pH}$ values of the solutions. The spectral measurements are carried out on a Varian Cary 50 spectrophotometer controlled by a computer and equipped with a $1 \mathrm{~cm}$ path length quartz cell, in the wavelength region from $190 \mathrm{~nm}$ to $400 \mathrm{~nm}$. The maximum scan rate is $24000 \mathrm{~nm} / \mathrm{min}$ and resolution is $1.5 \mathrm{~nm}$.

Excel program is applied for calculation of the dissociation constants, while the UV spectra are obtained with computer program Grams Version 4.10. 
Procedure for determination of dissociation constants

The hydrazones in basic media behaved as weak acids [24], hence their acid dissociation constants could be calculated using the changes in the UV spectra with $\mathrm{pH}$ of the medium. The dissociation of a weak acid could be defined as follows (Eq. (1)):

$$
\mathrm{BH}_{\mathrm{n}}=\mathrm{B}^{\mathrm{n}-}+\mathrm{nH}^{+}
$$

At constant ionic strength, the equilibrium constant of the dissociation reaction expressed using the concentration values is given with the Eq. (2), while Eq. (3) is used for calculations of the $\mathrm{p} K_{\mathrm{BH}}$.

$$
\begin{gathered}
K_{\mathrm{BH}}=\frac{c\left(\mathrm{~B}^{-}\right) \cdot c\left(\mathrm{H}^{+}\right)}{c(\mathrm{BH})} \cdot \frac{1}{c^{0}} \\
\mathrm{p} K_{\mathrm{BH}}=\mathrm{pH}+\log I
\end{gathered}
$$

In Eq. (3) $I$ is ionization ratio i.e. ratio between concentration of dissociated and neutral form of the hydrazone molecule, $I=c\left(\mathrm{~B}^{-}\right) / c(\mathrm{BH}), \mathrm{p} K_{\mathrm{BH}}$ is stoichiometric dissociation constant. The concentration of these two forms of the hydrazone presented in the solution are determined by resolving the overdetermined system of four equations (referred to the absorbance values at the analytical wavelengths) with two unknown parameters (the concentration of neutral and dissociated form). At the other hand, the calculations could be made from the absorbance values of a wavelength at maximum absorption, but the results obtained in this way are less precise. All the calculations are performed using the computer program Excel.

The $\mathrm{p} K_{\mathrm{BH}}$ values are obtained graphically, too. In fact, when $c\left(\mathrm{~B}^{-}\right)=$ $c(\mathrm{BH}), \log I=0$, and the graphically dissociation constant is equal to the $\mathrm{pH}$ value of solution $\left(\mathrm{p} K_{\mathrm{BH}}=\mathrm{pH}\right)$, i.e. the weak acid is half dissociated [25]. The thermodynamic dissociation constants are evaluated with extrapolation to zero ionic strength of the dependence $\mathrm{p} K_{\mathrm{BH}}$ (at ionic strength of $0.1,0.25$ and 0.5 $\mathrm{mol} \mathrm{dm}^{-3}$ ) on $\sqrt{\mu}$. 


\section{RESULT AND DISSCISION}

\section{Experimental spectra}

The influence of the acidity of the medium on the investigated hydrazones have been studied using the electronic absorption spectra recorded in solutions covering the range of $\mathrm{pH}$ from 7 to 14 , at wavelength intervals between 190 and $400 \mathrm{~nm}$. The spectra are recorded at ionic strength of $0.1,0.25$ and 0.5 $\mathrm{mol} \mathrm{dm} \mathrm{dm}^{-3}$. The obtained spectra at ionic strength of $0.1 \mathrm{~mol} \mathrm{dm}^{-3}$ for the hydrazones $\mathbf{H}_{4}$ and $\mathbf{H}_{5}$ are shown on the Fig. 1. The spectra for the hydrazones $\mathbf{H}_{1}$, $\mathbf{H}_{2}$ and $\mathbf{H}_{3}$ are dropped out, because they are similar to those of the hydrazone $\mathrm{H}_{4}$.
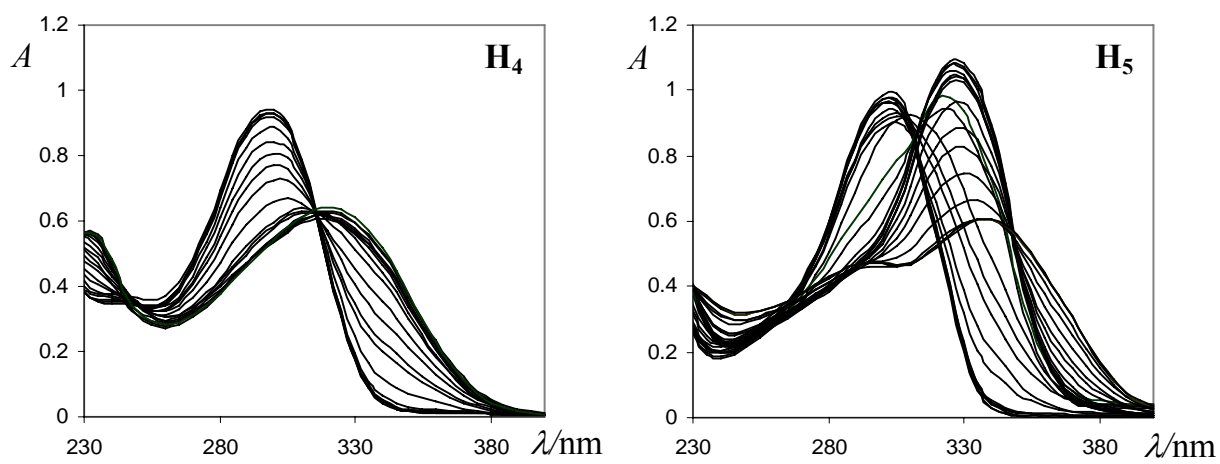

Fig. 1. UV spectra of hydrazones $\mathbf{H}_{4}$ and $\mathbf{H}_{5}\left(c=3.00 \cdot 10^{-5} \mathrm{~mol} \mathrm{dm}^{-3}\right)$ in solution with varying $\mathrm{pH}(7-14)$ and ionic strength of $0.1 \mathrm{~mol} \mathrm{dm}^{-3}$

The electronic absorption spectra of the hydrazone $\mathbf{H}_{4}$ display one absorption band in the wavelength region from 230 to $400 \mathrm{~nm}$ (See Fig. 1). Its maximum in solution with $\mathrm{pH} \approx 7.5$ appears at around $300 \mathrm{~nm}$ wavelength. This band is a result of a low energy $n \rightarrow \pi^{*}$ electron transition of the azometine group, and characterizes the neutral form of the compound. When the $\mathrm{pH}$ value of the solution increases (up to $\mathrm{pH}$ 9), the absorption band of the hydrazone $\mathbf{H}_{4}$ shifts towards longer wavelengths (around $320 \mathrm{~nm}$ ) and its intensity decrease (Fig. 1). At $\mathrm{pH}$ value around 11.6 its position and intensity does not change anymore. These changes in the UV spectra of hydrazone $\mathbf{H}_{4}$, probably are a result of dissociation of amide group. 
As it is expected, the changes in the experimental UV spectra of the hydrazone $\mathbf{H}_{5}$ are different than those mentioned above (See Fig. 1). When the $\mathrm{pH}$ of the solution increases from 7.9 to 10.2 the absorption band that appears in neutral media at $302 \mathrm{~nm}$ shiftes batochromic to $327 \mathrm{~nm}$, and its intensity increases. There are no changes in the position and intensity of this band up to $\mathrm{pH}$ value of the 10.3 and until 11.4. However, when the investigated solution becomes more basic (pH between 11.7 and 13.2) another batochromic shift to 340 $\mathrm{nm}$ is observed, and in this case the intensity of the absorption band decreased. There are no changes in the experimental spectra of the hydrazone $\mathbf{H}_{5}$ up to $\mathrm{pH}$ values of 13.2. According to the more acidic character of the hydroxyl group than amide group, the first band shift is due to dissociation of hydroxyl group, while the second one can be a result of dissociation of amide group.

The described changes in the UV spectra of the investigated hydrazones show that the dissociation reaction takes place in basic media. The positions of absorption band in neutral and in basic media, as well as, the molar absorption coefficient values $(\varepsilon)$ are given in Table 2 .

Ta b 1 e 2

$\lambda_{\max }, \varepsilon_{\max }$ and $\mathrm{pH}$ range of dissociation of the absorption band in neutral and basic media for the hydrazones $\mathbf{H}_{1}-\mathbf{H}_{5}\left(\mu=0.1 \mathrm{~mol} \mathrm{dm}^{-3}\right)$

\begin{tabular}{|c|c|c|c|c|c|c|c|}
\hline \multirow{2}{*}{ Compound } & \multicolumn{3}{|c|}{ Neutral form } & \multicolumn{3}{|c|}{ Dissociated form } & \multirow{2}{*}{$\begin{array}{l}\mathrm{pH} \text { range o } \\
\text { dissociation }\end{array}$} \\
\hline & $\mathrm{pH}$ & $\lambda_{\max }$ & ${ }^{*} \varepsilon \cdot 10^{3}$ & $\mathrm{pH}$ & $\lambda_{\max }$ & $\varepsilon \cdot 10^{3}$ & \\
\hline $\mathbf{H}_{1}$ & 7.9 & 297 & 289.7 & 11.9 & 318 & 161.3 & $9.8-11.6$ \\
\hline $\mathbf{H}_{2}$ & 7.8 & 298 & 274.8 & 11.2 & 320 & 163.9 & $9.5-11.2$ \\
\hline $\mathbf{H}_{3}$ & 7.4 & 302 & 361.1 & 11.3 & 325 & 182.2 & $9.9-11.3$ \\
\hline $\mathbf{H}_{4}$ & 7.2 & 298 & 260.7 & 11.3 & 317 & 213.5 & $9.8-11.3$ \\
\hline \multirow{2}{*}{$\mathbf{H}_{5}$} & \multirow{2}{*}{7.9} & \multirow{2}{*}{302} & \multirow{2}{*}{331.4} & 9.8 & 327 & 354.8 & $9.4-10.2$ \\
\hline & & & & 13.2 & 340 & 203.6 & $11.7-13.2$ \\
\hline
\end{tabular}

${ }^{*} \mathrm{dm}^{3} \mathrm{~mol}^{-1} \mathrm{~cm}^{-1}$ 


\section{Sigmoidal ,S” curves}

The changes in the absorbance values with the changes of the $\mathrm{pH}$ values of the solution could be better seen from the dependence of the absorbance of selected wavelengths on $\mathrm{pH}$. This dependence has sigmoidal form („S" curve) and it allows evaluating the $\mathrm{pH}$ region in which the dissociation process takes place. The „S" curves obtained for the hydrazones $\mathbf{H}_{\mathbf{4}}$ and $\mathbf{H}_{5}$ are shown in Fig 2.
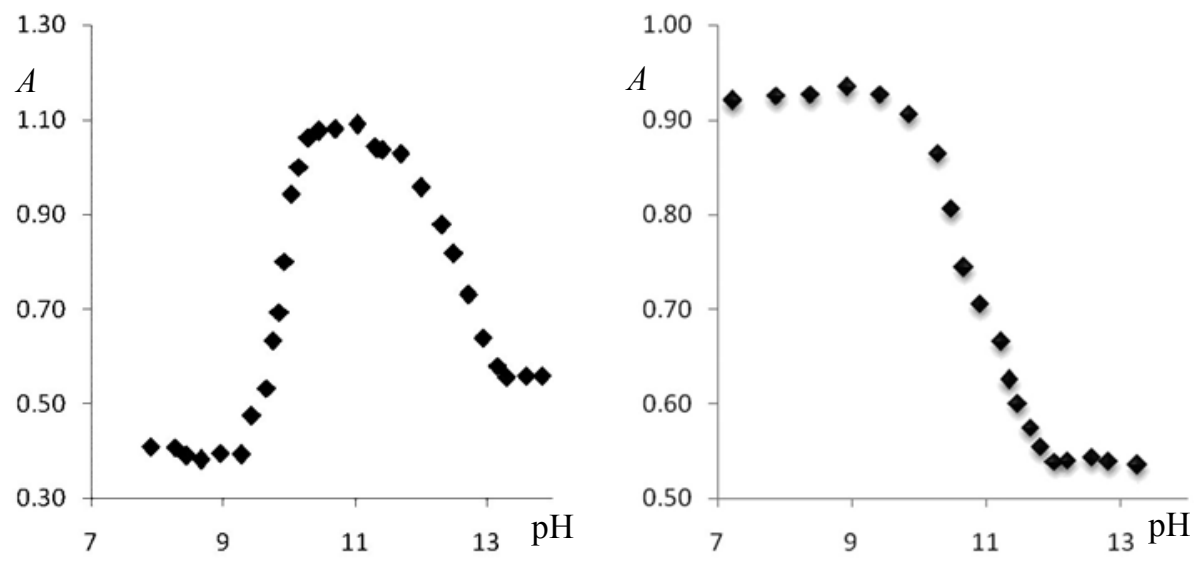

Fig. 2. The absorbance $v s$. $\mathrm{pH}$ plots at $\lambda_{300} \mathrm{~nm}$ for hydrazone $\mathbf{H}_{4}\left(c=3.00 \cdot 10^{-5} \mathrm{~mol} \mathrm{dm}^{-3}\right)$ and $\lambda_{325} \mathrm{~nm}$ for hydrazone $\mathbf{H}_{5}\left(c=3.00 \cdot 10^{-5} \mathrm{~mol} \mathrm{dm}^{-3}\right)$ at ionic strength of $0.1 \mathrm{~mol} \mathrm{dm}^{-3}$ (reconstructed spectra)

From the Fig. 2 it can be seen that the absorbance values are constant between $\mathrm{pH}$ values of 7 and 9.5, and in the solution probably the molecular form of the investigated compound is dominant. Furthermore, the absorbance values increase in the $\mathrm{pH}$ range from 9.5 to 11.5 , and in this range the dissociation process of the hydrazone $\mathbf{H}_{4}$ occurs. Above $\mathrm{pH}$ of 11.5 the absorbance value of the dissociated form is higher than that of the molecular form. The curve $A_{\lambda \max }=f(\mathrm{pH})$ of the hydrazone $\mathbf{H}_{4}$ (Fig. 2) displays one step, which means that the dissociation process take place in one step. The same situation is observed for the hydrazones $\mathbf{H}_{1}, \mathbf{H}_{2}$ and $\mathbf{H}_{3}$. As it is mentioned before, the dissociated proton belongs to the amide group.

In addition, as it is expected ,the ,S" curve of the hydrazone $\mathbf{H}_{5}$ has two steps. The first step is observed in the $\mathrm{pH}$ range from 9.4 and 10.2 (first 
step of dissociation) and the second one between 11.7 and 13.2 (second step of dissociation).

These two clear steps on the „S" curve of the hydrazone $\mathbf{H}_{5}$ (Fig. 2) indicate the establishment of two acid-base equilibriums over the used $\mathrm{pH}$ range. Ionization of the hydroxyl group occurs first, than follows ionization of the amide group.

\section{Semiempirical data}

In order to confirm the conclusions that are obtained from the experimental spectra and sigmoidal ,S" curves, we made some semiempirical calculations. The deprotonation enthalpy (DPE) of compound HB is the heat of reaction for loss of a proton to form the conjugate base as it is given with the Eq. (1). DPE is the characteristic of a neutral molecule and it could be calculated according to Eq. (4).

$$
\mathrm{DPE}(\mathrm{BH})=\Delta H_{f}\left(\mathrm{H}^{+}\right)+\Delta H_{f}\left(\mathrm{~B}^{-}\right)-\Delta H_{f}(\mathrm{BH})
$$

In the Eq. (4), $\Delta H_{f}\left(\mathrm{H}^{+}\right)$is the heat of formation of $\mathrm{H}^{+}$and its experimental value is $367.2 \mathrm{kcal} \mathrm{mol}^{-1}$ [26], while $\Delta H_{f}(\mathrm{BH})$ and $\Delta H_{f}\left(\mathrm{~B}^{-}\right)$are the heats of formation of neutral and dissociated forms, respectively. The heats of formation, total energies and the calculated DPE values of the investigated hydrazones are presented in Table 3.

The obtained semiemirical data show that the DPE values of the amide group are similar for the investigated hydrazones $\mathbf{H}_{1}-\mathbf{H}_{3}$, and theirs values are around $333 \mathrm{kcal} \mathrm{mol}^{-1}$ (Table 3). It suggests that the substituents $-\mathrm{CH}_{3}$ and $-\mathrm{OCH}_{3}$ have no important influence of the dissociation reaction. The hydrazones $\mathbf{H}_{4}$ and $\mathbf{H}_{5}$ have a little lower values of DPE compared to the hydrazones $\mathbf{H}_{1}-\mathbf{H}_{3}$, probably due to the presence of the $-\mathrm{Cl}$ and $-\mathrm{OH}$ group in their molecule, but still these differences are not significant. The situation is different for the hydrazone $\mathbf{H}_{5}$ which has two dissociable groups (Table 3). The DPE values of the hydroxyl group are higher than the DPE values of the amide group. It shows that the deprotonation of the hydroxyl group occurs first, which is in accordance with the above performed conclusions. This is also in agreement with the experimental data (Table 3) and the data known from the literature [27]. Furthermore, the values of the total energy are similar for the neutral and dissociated form for all investigated hydrazones. It means that the both forms exist in 
equilibrium in the solution. On the other hand, the total energy value of the hydrazone $\mathbf{H}_{5}$ when the both groups $(-\mathrm{NH}$ and $-\mathrm{OH})$ are dissociated is lower compared to the neutral form, suggesting that these dissociated form are more stable. The experimental results obtained for the investigated hydrazones, as well as the calculated DPE values suggest the following sites of deprotonation:

T a b le 3

Semiempirical data ( $E_{\mathrm{tot}}, \Delta H_{f}$ and DPE) of hydrazones $\mathbf{H}_{\mathbf{1}}-\mathbf{H}_{\mathbf{5}}$

\begin{tabular}{|c|c|c|c|c|c|}
\hline \multicolumn{6}{|c|}{ AM1 } \\
\hline Compound & $E_{\mathrm{tot}}(\mathrm{BH})$ & $E_{\mathrm{tot}}\left(\mathrm{B}^{-}\right)$ & $\Delta H_{f}(\mathrm{BH})$ & $\Delta H_{f}\left(\mathrm{~B}^{-}\right)$ & DPE \\
\hline $\mathbf{H}_{1}$ & -62028.4 & -61747.5 & 59.42 & 25.44 & 333.21 \\
\hline $\mathbf{H}_{2}$ & -65623.1 & -65341.8 & 51.54 & 17.94 & 333.59 \\
\hline $\mathbf{H}_{3}$ & -73003.1 & -72722.0 & 20.74 & -13.04 & 333.42 \\
\hline $\mathbf{H}_{4}$ & -70332.7 & -70054.5 & 52.49 & 15.82 & 330.52 \\
\hline $\mathbf{H}_{5}$ & ${ }^{1}-69422.5$ & -69141.9 & 14.49 & -19.86 & 332.85 \\
\hline & 2 & -68796.9 & & 10.28 & 362.99 \\
\hline \multicolumn{6}{|c|}{ PM3 } \\
\hline $\mathbf{H}_{1}$ & -56718.2 & -56405.7 & 55.76 & 14.71 & 326.15 \\
\hline $\mathbf{H}_{2}$ & -60170.9 & -59858.1 & 46.18 & 5.473 & 326.48 \\
\hline $\mathbf{H}_{3}$ & -66932.1 & -66620.1 & 17.07 & -24.48 & 325.64 \\
\hline $\mathbf{H}_{4}$ & -63669.1 & -63358.5 & 49.02 & 6.036 & 324.22 \\
\hline \multirow[t]{2}{*}{$\mathbf{H}_{5}$} & ${ }^{1}-63496.1$ & -63184.4 & 9.931 & -31.86 & 325.40 \\
\hline & 2 & -62803.5 & & -4.547 & 352.72 \\
\hline
\end{tabular}

Units for $E_{\mathrm{tot}}, \Delta H_{f}$ and DPE are $\mathrm{kcal} / \mathrm{mol}$

As it is already mentioned, the Scheme 1 shows that hydrazones $\mathbf{H}_{1}-\mathbf{H}_{4}$ possess one site of dissociation i.e. amide group in their molecule. On the other hand, hydrazone $\mathbf{H}_{5}$ has two sites of dissociation. In spite of amide group, the hydroxyl group dissociates, too. 
<smiles></smiles><smiles>O=C(NN=Cc1ccccc1)c1ccc(O)cc1</smiles>

Scheme 1. Possible sites of dissociation of hydrazone molecule

Determination of the dissociation constants, $p K_{B H}$

The dissociation constants of investigated hydrazones are determined by varying $\mathrm{pH}$ (up to 7) in aqueous sodium hydroxide media. Another important factor which has influence on the determination of the $\mathrm{p} K_{\mathrm{BH}}$ values is the ionic strength of the solution. It affects the activity coefficients of the ionic species in equilibrium. Hence, the procedure of determination is performed at constant ionic strength of $0.1,0.25$ and $0.5 \mathrm{~mol} \mathrm{dm}^{-3}$, as it is mentioned before. The measurements are done at different strengths in order to determine the thermodynamic dissociation constants. Furthermore, the measurements are repeated twice in order to confirm the obtained results.

The variation of absorbance with $\mathrm{pH}$ of the solutions is utilized for calculation of the $\mathrm{p} K_{\mathrm{BH}}$. In order to achieve more precise results the absorbance values at four analytical wavelengths are used. The absorbance values at 290 , 295,300 and $305 \mathrm{~nm}$ of the band that appears at about $300 \mathrm{~nm}$ wavelength for the hydrazones $\mathbf{H}_{1}-\mathbf{H}_{4}$ and the absorbance values at $315,320,325$ and $330 \mathrm{~nm}$ of the band that appears at $325 \mathrm{~nm}$ for the hydrazone $\mathbf{H}_{5}$ are chosen as the analytical ones for determining the $\mathrm{p} K_{\mathrm{BH}}$ values. The changes in the absorbance values with increasing the basicity of the solutions are bigger around the absorption maximum i.e. the „S" curves are the best when these absorbance values are used. The absorbances used for the calculation of the $\mathrm{p} K_{\mathrm{BH}}$ values and ionization ratio $(\log I)$ values at ionic strength of $0.1 \mathrm{~mol} \mathrm{dm}^{-3}$ are shown in Tables 4,5 and 6 . 
T a b le 4

The absorbance values at the selected wavelength and ionization ratio (I) values of the hydrazones $\mathbf{H}_{\mathbf{1}}$ and $\mathbf{H}_{\mathbf{2}}$

\begin{tabular}{|c|c|c|c|c|c|c|c|c|c|c|c|}
\hline \multicolumn{6}{|c|}{$\mathbf{H}_{1}$} & \multicolumn{6}{|c|}{$\mathbf{H}_{2}$} \\
\hline $\mathrm{pH}$ & $\log I$ & $A_{290}$ & $A_{295}$ & $A_{300}$ & $A_{305}$ & $\mathrm{pH}$ & $\log I$ & $A_{290}$ & $A_{295}$ & $A_{300}$ & $A_{305}$ \\
\hline 7.98 & & 0.7654 & 0.7994 & 0.7959 & 0.7502 & 7.88 & & 0.7905 & 0.8381 & 0.8446 & 0.8091 \\
\hline 8.41 & & 0.7500 & 0.7804 & 0.7776 & 0.7320 & 8.22 & & 0.7813 & 0.8266 & 0.8322 & 0.7981 \\
\hline 8.82 & & 0.7693 & 0.8004 & 0.7967 & 0.7486 & 8.31 & & 0.7789 & 0.8232 & 0.8302 & 0.7940 \\
\hline 9.18 & & 0.7679 & 0.7977 & 0.7926 & 0.7454 & 8.59 & & 0.7859 & 0.8331 & 0.8391 & 0.8035 \\
\hline 9.36 & & 0.7516 & 0.7824 & 0.7770 & 0.7289 & 8.82 & & 0.7867 & 0.8333 & 0.8395 & 0.8058 \\
\hline 9.61 & & 0.7599 & 0.7898 & 0.7841 & 0.7352 & 9.18 & & 0.7859 & 0.8336 & 0.8379 & 0.8038 \\
\hline 9.88 & 0.7841 & 0.7299 & 0.7577 & 0.7428 & 0.7158 & 9.48 & 1.0328 & 0.7343 & 0.7755 & 0.7809 & 0.7496 \\
\hline 10.19 & 0.4223 & 0.7099 & 0.7377 & 0.7328 & 0.7055 & 9.71 & 0.8598 & 0.6943 & 0.7355 & 0.7409 & 0.7115 \\
\hline 10.28 & 0.3292 & 0.6932 & 0.7198 & 0.7157 & 0.6922 & 9.97 & 0.5883 & 0.6599 & 0.6976 & 0.7004 & 0.6795 \\
\hline 10.60 & 0.0759 & 0.6627 & 0.6889 & 0.6852 & 0.6736 & 10.29 & 0.2487 & 0.6148 & 0.6504 & 0.6598 & 0.6409 \\
\hline 10.89 & -0.2421 & 0.6211 & 0.6474 & 0.6490 & 0.6494 & 10.58 & -0.1045 & 0.5813 & 0.6161 & 0.6270 & 0.6179 \\
\hline 11.22 & -0.5863 & 0.5696 & 0.5969 & 0.6029 & 0.6152 & 10.95 & -0.3967 & 0.5453 & 0.5782 & 0.5931 & 0.5901 \\
\hline 11.41 & -0.8056 & 0.5107 & 0.5363 & 0.5452 & 0.5609 & 11.24 & -0.6704 & 0.4800 & 0.5120 & 0.5314 & 0.5288 \\
\hline 11.63 & -0.9626 & 0.4732 & 0.5003 & 0.5137 & 0.5258 & 11.62 & & 0.4264 & 0.4556 & 0.4767 & 0.4907 \\
\hline 11.94 & & 0.4077 & 0.4324 & 0.4485 & 0.4552 & 11.91 & & 0.4059 & 0.4344 & 0.4571 & 0.4741 \\
\hline 12.24 & & 0.3922 & 0.4234 & 0.4395 & 0.4528 & 12.18 & & 0.3974 & 0.4245 & 0.4445 & 0.4651 \\
\hline 12.45 & & 0.3858 & 0.4167 & 0.4322 & 0.4534 & 12.54 & & 0.3875 & 0.4118 & 0.4320 & 0.4516 \\
\hline 12.66 & & 0.3809 & 0.4113 & 0.4374 & 0.4591 & 12.81 & & 0.3596 & 0.3908 & 0.4173 & 0.4442 \\
\hline 12.94 & & 0.3720 & 0.4003 & 0.4245 & 0.4460 & 13.16 & & 0.3396 & 0.3708 & 0.3973 & 0.4242 \\
\hline
\end{tabular}


Ta b le 5

The absorbance values at the selected wavelength and ionization ratio (I) values of the hydrazones $\mathbf{H}_{\mathbf{3}}$ and $\mathbf{H}_{\mathbf{4}}$

\begin{tabular}{|c|c|c|c|c|c|c|c|c|c|c|c|}
\hline \multicolumn{6}{|c|}{$\mathbf{H}_{3}$} & \multicolumn{6}{|c|}{$\mathrm{H}_{4}$} \\
\hline $\mathrm{pH}$ & $\log I$ & $A_{290}$ & $A_{295}$ & $A_{300}$ & $A_{305}$ & $\mathrm{pH}$ & $\log I$ & $A_{290}$ & $A_{295}$ & $A_{300}$ & $A_{305}$ \\
\hline 7.48 & & 0.8794 & 0.9815 & 1.0335 & 1.0338 & 7.23 & & 0.8600 & 0.9126 & 0.9204 & 0.8818 \\
\hline 7.74 & & 0.8849 & 0.9864 & 1.0374 & 1.0377 & 7.88 & & 0.8679 & 0.9204 & 0.9291 & 0.8898 \\
\hline 8.05 & & 0.8569 & 0.9539 & 1.0028 & 1.0025 & 8.39 & & 0.8690 & 0.9198 & 0.9293 & 0.8880 \\
\hline 8.27 & & 0.8842 & 0.9825 & 1.0329 & 1.0338 & 8.93 & & 0.8715 & 0.9237 & 0.9314 & 0.8917 \\
\hline 8.56 & & 0.8731 & 0.9667 & 1.0115 & 1.0074 & 9.42 & & 0.8846 & 0.9347 & 0.9417 & 0.9020 \\
\hline 8.8 & & 0.8750 & 0.9682 & 1.0139 & 1.0115 & 9.85 & 0.6036 & 0.8232 & 0.8711 & 0.8862 & 0.8513 \\
\hline 9.01 & & 0.8647 & 0.9592 & 1.0024 & 0.9968 & 10.28 & 0.1801 & 0.7815 & 0.8288 & 0.8437 & 0.8255 \\
\hline 9.21 & & 0.8658 & 0.9554 & 0.9978 & 0.9926 & 10.48 & -0.0818 & 0.7370 & 0.7889 & 0.8085 & 0.7965 \\
\hline 9.54 & & 0.8837 & 0.9767 & 1.0164 & 1.0145 & 10.67 & -0.1625 & 0.6995 & 0.7481 & 0.7693 & 0.7604 \\
\hline 9.72 & & 0.8698 & 0.9620 & 1.0051 & 1.0019 & 10.91 & -0.4613 & 0.6508 & 0.6977 & 0.7238 & 0.7251 \\
\hline 9.91 & 0.5079 & 0.8433 & 0.9284 & 0.9691 & 0.9551 & 11.22 & -0.7872 & 0.5865 & 0.6310 & 0.6591 & 0.6688 \\
\hline 10.15 & 0.3636 & 0.8096 & 0.8950 & 0.9341 & 0.9291 & 11.35 & -0.8949 & 0.5208 & 0.5636 & 0.5968 & 0.5993 \\
\hline 10.34 & 0.0067 & 0.7585 & 0.8330 & 0.8710 & 0.8729 & 11.47 & & 0.5061 & 0.5525 & 0.5849 & 0.5907 \\
\hline 10.59 & -0.1405 & 0.7106 & 0.7772 & 0.8107 & 0.8149 & 11.66 & & 0.4953 & 0.5398 & 0.5759 & 0.5839 \\
\hline 10.87 & -0.4114 & 0.6399 & 0.6988 & 0.7286 & 0.7427 & 11.81 & & 0.4667 & 0.5084 & 0.5440 & 0.5758 \\
\hline 11.08 & -0.6303 & 0.5844 & 0.6328 & 0.6606 & 0.6752 & 12.02 & & 0.4689 & 0.5054 & 0.5381 & 0.5710 \\
\hline 11.31 & -0.8937 & 0.5015 & 0.5358 & 0.5596 & 0.5702 & 12.21 & & 0.4658 & 0.5040 & 0.5367 & 0.5675 \\
\hline 11.63 & & 0.4473 & 0.4722 & 0.4928 & 0.5092 & 12.57 & & 0.4661 & 0.5108 & 0.5490 & 0.5822 \\
\hline 11.94 & & 0.4373 & 0.4721 & 0.5039 & 0.5299 & 12.82 & & 0.4659 & 0.5092 & 0.5481 & 0.5827 \\
\hline 12.28 & & 0.4418 & 0.4699 & 0.4954 & 0.5217 & 13.25 & & 0.4586 & 0.5025 & 0.5435 & 0.5807 \\
\hline
\end{tabular}


T a b le 6

The absorbance values at the selected wavelength and ionization ratio (I) values of the hydrazone $\mathbf{H}_{5}$

\begin{tabular}{|c|c|c|c|c|c|c|c|c|c|c|c|}
\hline \multicolumn{6}{|c|}{$\mathbf{H}_{5}$ first dissociatin } & \multicolumn{6}{|c|}{$\mathbf{H}_{5}$ second dissociation } \\
\hline $\mathrm{pH}$ & $\log I$ & $\mathrm{~A}_{320}$ & $\mathrm{~A}_{325}$ & $\mathrm{~A}_{330}$ & $A_{335}$ & $\mathrm{pH}$ & $\log \mathrm{I}$ & $\mathrm{A}_{320}$ & $\mathrm{~A}_{325}$ & $\mathrm{~A}_{330}$ & $\mathrm{~A}_{335}$ \\
\hline 7.91 & & 0.5850 & 0.4068 & 0.2259 & 0.0974 & 11.05 & & 1.0305 & 1.0898 & 1.0864 & 1.0223 \\
\hline 8.28 & & 0.5752 & 0.4054 & 0.2302 & 0.1069 & 11.31 & & 0.9870 & 1.0433 & 1.0381 & 0.9807 \\
\hline 8.45 & & 0.5643 & 0.3880 & 0.2116 & 0.0873 & 11.43 & & 0.9781 & 1.0361 & 1.0346 & 0.9737 \\
\hline 8.68 & & 0.5554 & 0.3800 & 0.2061 & 0.0839 & 11.71 & $0.9217]$ & 0.9692 & 1.0269 & 1.0259 & 0.9712 \\
\hline 8.97 & & 0.5611 & 0.3924 & 0.2203 & 0.0986 & 12.02 & $0.6251]$ & 0.9021 & 0.9558 & 0.9583 & 0.9115 \\
\hline 9.29 & & 0.5646 & 0.3912 & 0.2178 & 0.0968 & 12.33 & 0.2904 & 0.8273 & 0.8765 & 0.8864 & 0.8495 \\
\hline 9.44 & 0.5804 & 0.6061 & 0.4737 & 0.3401 & 0.2797 & 12.51 & 0.1193 & 0.7669 & 0.8157 & 0.8257 & 0.7983 \\
\hline 9.67 & 0.4147 & 0.6566 & 0.5309 & 0.4087 & 0.3465 & 12.74 & -0.1659 & 0.6873 & 0.7296 & 0.7448 & 0.7319 \\
\hline 9.77 & 0.3219 & 0.7477 & 0.6325 & 0.5198 & 0.4097 & 12.96 & -0.3891 & 0.5995 & 0.6370 & 0.6583 & 0.6513 \\
\hline 9.86 & 0.2042 & 0.7939 & 0.6925 & 0.5798 & 0.4827 & 13.18 & -0.4842 & 0.5434 & 0.5784 & 0.5858 & 0.5965 \\
\hline 9.94 & 0.0757 & 0.8793 & 0.7983 & 0.6969 & 0.5802 & 13.32 & & 0.5204 & 0.5546 & 0.5844 & 0.6029 \\
\hline 10.05 & -0.0152 & 0.9346 & 0.9411 & 0.7567 & 0.6757 & 13.61 & & 0.5226 & 0.5569 & 0.5866 & 0.6051 \\
\hline 10.16 & -0.1007 & 0.9994 & 0.9985 & 0.8712 & 0.7361 & 13.85 & & 0.5233 & 0.5575 & 0.5873 & 0.6058 \\
\hline 10.30 & & 1.0127 & 1.0612 & 1.0468 & 0.9785 & & & & & & \\
\hline 10.47 & & 1.0196 & 1.0761 & 1.0655 & 1.0011 & & & & & & \\
\hline 10.71 & & 1.0203 & 1.0800 & 1.0744 & 1.0132 & & & & & & \\
\hline
\end{tabular}

Using the absorbance values at the selected wavelengths the molar absorption coefficients are calculated according to Beer's low. To achieve that, the UV spectra are recorded at three different concentrations of the investigated hydrazones: $2.40 \cdot 10^{-5} \mathrm{~mol} \mathrm{dm}{ }^{-3}, 3.00 \cdot 10^{-5} \mathrm{~mol} \mathrm{dm} \mathrm{dm}^{-3}$ and $3.60 \cdot 10^{-5} \mathrm{~mol} \mathrm{dm}$. The measurements are performed at $\mathrm{pH}$ values in which the investigated hydrazones $\mathbf{H}_{1}-\mathbf{H}_{5}$ exist in neutral and dissociated form. Next step is the calculation of the ionization ratio $(I)$ values using the absorbances and molar absorption coefficients. The $\mathrm{p} K_{\mathrm{BH}}$ values of the investigated hydrazones are calculated by using the Eq. (3), given in the experimental section. The obtained $\mathrm{p} K_{\mathrm{BH}}$ values determined with this procedure and their confidence interval at $95 \%$ confidence levels, standard deviation values $(s)$, variances $(V)$ and correlation coefficients 
$(R)$ are presented in Table 7. All the calculations are performed using the computer program Excel.

\section{T a b le 7}

Stoichiometric $\mathrm{p} K_{\mathrm{BH}}$ values (numerically and graphically), thermodynamic dissociation constant of hydrazones $\mathbf{H}_{1}-\mathbf{H}_{5}$ and statistical data $(s, V \%, R)$

\begin{tabular}{|c|c|c|c|c|c|c|}
\hline & \multicolumn{3}{|l|}{$\mathbf{H}_{1}$} & \multicolumn{3}{|l|}{$\mathbf{H}_{2}$} \\
\hline & $\mu=0.1$ & $\mu=0.25$ & $\mu=0.5$ & $\mu=0.1$ & $\mu=0.25$ & $\mu=0.5$ \\
\hline $\mathrm{p} K_{\mathrm{BH}}^{1}$ & $\begin{array}{c}10.63 \pm 0.02 \\
* \mathrm{n}=8\end{array}$ & $\begin{array}{c}10.66 \pm 0.01 \\
n=8\end{array}$ & $\begin{array}{c}10.70 \pm 0.01 \\
\mathrm{n}=8\end{array}$ & $\begin{array}{c}10.53 \pm 0.02 \\
\mathrm{n}=7\end{array}$ & $\begin{array}{c}10.56 \pm 0.02 \\
n=8\end{array}$ & $\begin{array}{c}10.60 \pm 0.02 \\
n=8\end{array}$ \\
\hline $\mathrm{p} K_{\mathrm{BH}}^{2}$ & 10.63 & 10.65 & 10.68 & 10.47 & 10.50 & 10.54 \\
\hline$S$ & 0.028 & 0.014 & 0.020 & 0.034 & 0.036 & 0.031 \\
\hline$V \%$ & 0.26 & 0.13 & 0.19 & 0.33 & 0.34 & 0.29 \\
\hline$R$ & 0.998 & 0.999 & 0.999 & 0.998 & 0.998 & 0.998 \\
\hline \multicolumn{7}{|c|}{ Thermodynamic $\mathrm{p} K_{\mathrm{BH}}$} \\
\hline \multicolumn{3}{|c|}{ Numerically } & 10.58 & & & 10.47 \\
\hline \multicolumn{3}{|c|}{ Graphically } & 10.58 & & & 10.40 \\
\hline & \multicolumn{3}{|c|}{$\mathbf{H}_{3}$} & \multicolumn{3}{|c|}{$\mathrm{H}_{4}$} \\
\hline $\mathrm{p} K_{\mathrm{BH}}^{1}$ & $\begin{array}{c}10.43 \pm 0.04 \\
n=7\end{array}$ & $\begin{array}{c}10.45 \pm 0.03 \\
\mathrm{n}=7\end{array}$ & $\begin{array}{c}10.49 \pm 0.02 \\
n=7\end{array}$ & $\begin{array}{c}10.45 \pm 0.02 \\
\mathrm{n}=7\end{array}$ & $\begin{array}{c}10.47 \pm 0.01 \\
\mathrm{n}=7\end{array}$ & $\begin{array}{c}10.50 \pm 0.02 \\
\mathrm{n}=7\end{array}$ \\
\hline $\mathrm{p} K_{\mathrm{BH}}^{2}$ & 10.44 & 10.46 & 10.50 & 10.47 & 10.49 & 10.52 \\
\hline$s$ & 0.051 & 0.035 & 0.025 & 0.033 & 0.012 & 0.032 \\
\hline$V \%$ & 0.48 & 0.34 & 0.24 & 0.31 & 0.11 & 0.31 \\
\hline$R$ & 0.995 & 0.997 & 0.998 & 0.998 & 0.999 & 0.999 \\
\hline \multicolumn{7}{|c|}{ Thermodynamic $\mathrm{p} K_{\mathrm{BH}}$} \\
\hline \multicolumn{3}{|c|}{ Numerically } & 10.38 & & & 10.40 \\
\hline \multicolumn{3}{|c|}{ Graphically } & 10.39 & & & 10.43 \\
\hline & \multicolumn{3}{|c|}{$\mathbf{H}_{5}$ First dissociation constant } & \multicolumn{3}{|c|}{$\mathbf{H}_{5}$ Second dissociation constant } \\
\hline $\mathrm{p} K_{\mathrm{BH}}{ }^{1}$ & $\begin{array}{c}10.05 \pm 0.02 \\
n=7\end{array}$ & $\begin{array}{c}10.07 \pm 0.01 \\
n=7\end{array}$ & $\begin{array}{c}10.12 \pm 0.01 \\
n=7\end{array}$ & $\begin{array}{c}12.62 \pm 0.03 \\
n=7\end{array}$ & $\begin{array}{c}12.64 \pm 0.01 \\
n=7\end{array}$ & $\begin{array}{c}12.67 \pm 0.02 \\
n=7\end{array}$ \\
\hline $\mathrm{p} K_{\mathrm{BH}}^{2}$ & 10.06 & 10.08 & 10.13 & 12.65 & 12.68 & 12.72 \\
\hline$S$ & 0.030 & 0.01 & 0.01 & 0.043 & 0.014 & 0.022 \\
\hline$V \%$ & 0.30 & 0.09 & 0.08 & 0.34 & 0.11 & 0.17 \\
\hline$R$ & 0.992 & 0.999 & 0.999 & 0.996 & 0.999 & 0.999 \\
\hline \multicolumn{7}{|c|}{ Thermodynamic $\mathrm{p} K_{\mathrm{BH}}$} \\
\hline \multicolumn{3}{|c|}{ Numerically } & 9.99 & & & 12.57 \\
\hline \multicolumn{3}{|c|}{ Graphically } & $\mathbf{1 0 . 0 0}$ & & & 12.58 \\
\hline
\end{tabular}

$\mathrm{p} K_{\mathrm{BH}}{ }^{1}$ numerically, $\mathrm{p} K_{\mathrm{BH}}{ }^{2}$ graphically, $s$ - standard deviation, $V \%$ - variances, $R$ - correlation coefficient, ${ }^{*}$ number of data used for calculations 
When we arranged the $\mathrm{p} K_{\mathrm{BH}}$ value of the studied hydrazones $\mathbf{H}_{1}-\mathbf{H}_{4}$ for the first dissociation constant, and second one for hydrazone $\mathbf{H}_{5}$, we got the following order: $\mathbf{H}_{1}, \mathbf{H}_{2}, \mathbf{H}_{3}, \mathbf{H}_{4}$ and $\mathbf{H}_{5}$ (Table 7). The hydrazone $\mathbf{H}_{5}$ has higher $\mathrm{p} K_{\mathrm{BH}}$ value for the dissociation of the amide group compared to the $\mathrm{p} K_{\mathrm{BH}}$ of the other hydrazones, probably as a result of the influence of the hydroxyl group in their molecule. At the other hand, the $\mathrm{p} K_{\mathrm{BH}}$ values of hydrazones $\mathbf{H}_{1}-\mathbf{H}_{4}$ are similar. Even more, the hydrazones $\mathbf{H}_{3}$ and $\mathbf{H}_{\mathbf{4}}$ have identical $\mathrm{p} K_{\mathrm{BH}}$ values. These results suggest that the influence of $-\mathrm{CH}_{3},-\mathrm{OCH}_{3}$ and $-\mathrm{Cl}$ compared to $\mathrm{H}$ is insignificant. At higher ionic strength of the solutions, the $\mathrm{p} K_{\mathrm{BH}}$ values are higher, too, for all investigated hydrazones. The graphically evaluated $\mathrm{p} K_{\mathrm{BH}}$ values are in agreement with calculated ones (See Table 7). In the Fig. 3 are presented the graphically obtained $\mathrm{p} K_{\mathrm{BH}}$ values of the hydrazone $\mathbf{H}_{5}$ for the first and second dissociation step.
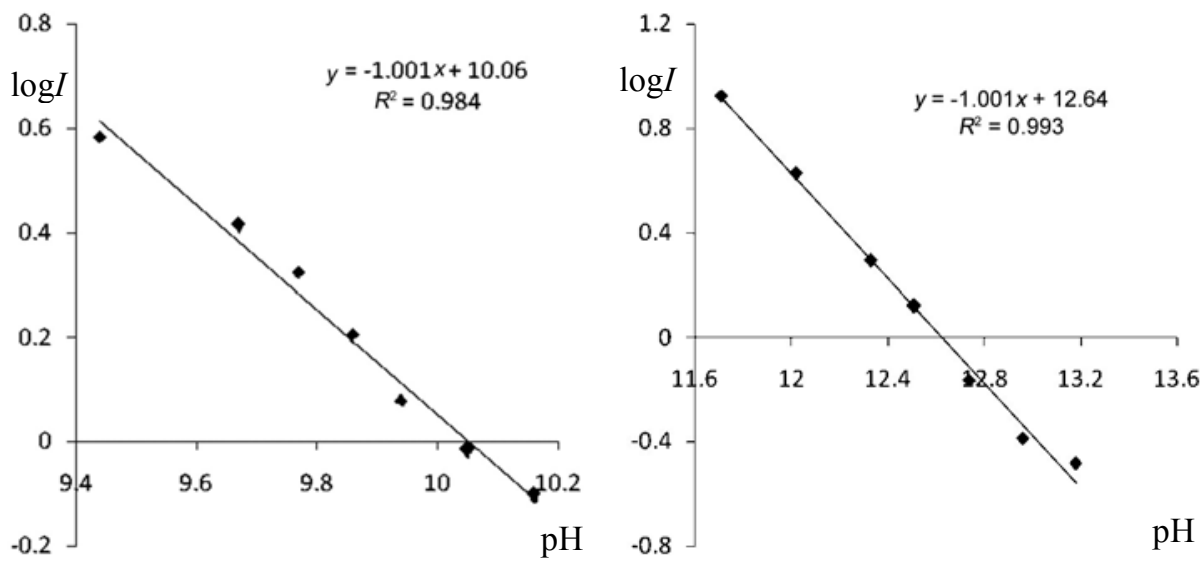

Fig. 3. Dependence of $\log I$ on $\mathrm{pH}$ of first (9.44-10.16) and second (11.71-13.18) dissociation step for hydrazone $\mathbf{H}_{5}\left(c=3.00 \cdot 10^{-5} \mathrm{~mol} \mathrm{dm}^{-3}\right)-$ ionic strength of $0.1 \mathrm{~mol} \mathrm{dm}^{-3}$

The statistical data ( $s$ and $V$ ) suggest that the used method for calculation of the $\mathrm{p} K_{\mathrm{BH}}$ is correct. The correlation between $\log I$ and $\mathrm{pH}$ is satisfactory ( $R$ is close to 1 ). 


\section{Thermodynamic dissociation constants}

Determination of the thermodynamic dissociation constants is done graphically. Namely, the curve of the dependence of $\mathrm{p} K_{\mathrm{BH}}$ (obtained for different ionic strength $0.1,0.25$ and $0.5 \mathrm{~mol} \mathrm{dm}^{-3}$ ) on square root of $\mu$ is extrapolated to zero ionic strength. The intercept of this dependence is equal to the thermodynamic dissociation constant.

The dependence of calculated $\mathrm{p} K_{\mathrm{BH}}$ at ionic strengths of $0.1,0.25$ and $0.5 \mathrm{~mol} \mathrm{dm}^{-3}$ on $\sqrt{\mu}$ for hydrazone $\mathbf{H}_{5}$, is presented on Fig. 4 .
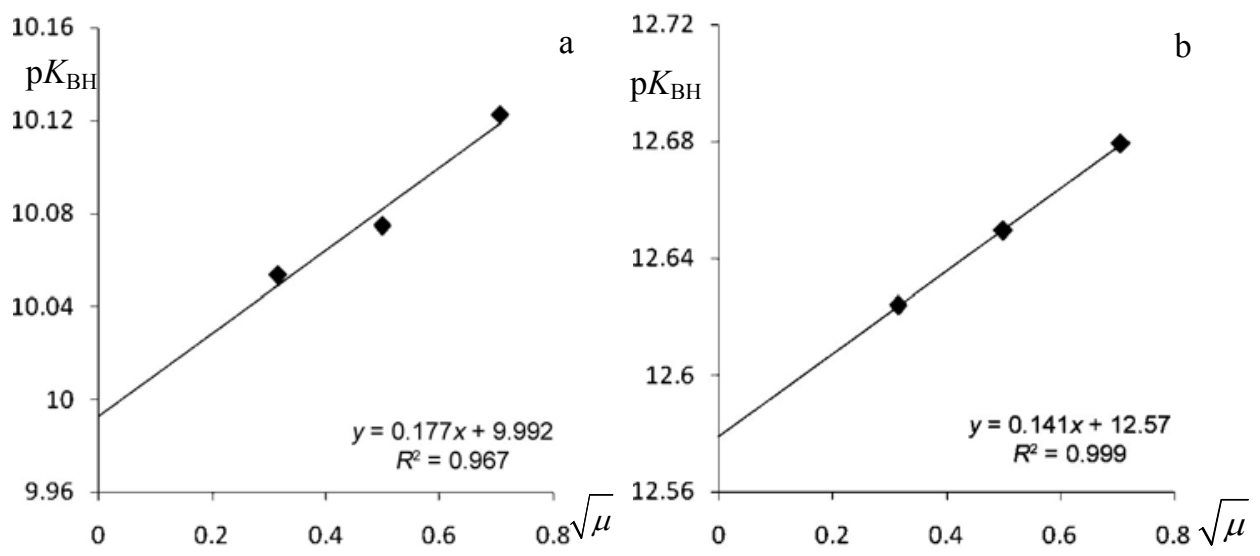

Fig. 4. Thermodynamic dissociation constant of hydrazone $\mathbf{H}_{5}\left(c=3.00 \cdot 10^{-5} \mathrm{~mol} \mathrm{dm}^{-3}\right)$, first (a) and second dissociation constant (b)

The evaluated thermodynamic $\mathrm{p} K_{\mathrm{BH}}$ values for all investigated hydrazones are shown in Table 5.

\section{CONCLUSION}

This study is carried out in order to determine the $\mathrm{p} K_{\mathrm{BH}}$ values of five $p$-substituted aromatic hydrazones. For that purpose, the spectrophotometric method is applied. The spectral behavior of the investigated aromatic hydrazones is followed in basic media i.e. in $\mathrm{pH}$ region from 7 to 14 . It is found that 
in aqueous sodium hydroxide solutions, the electronic absorption spectra are sensitive to $\mathrm{pH}$ variation. The "S" curves as well as, the isosbestic points observed in the spectra, indicated that one acid-base reaction for the hydrazones $\mathbf{H}_{1}-\mathbf{H}_{4}$, which involved the dissociation of the amide group, take place. On the other hand, for the hydrazone $\mathbf{H}_{5}$ two acid-base equilibriums are observed i.e. in spite of amide group, dissociation process occurrs in the hydroxyl group. The semiempirical methods (AM1 and PM3) are useful for studying processes that involve deprotonation of neutral molecules. The obtained semiempirical data show the deprotonation site and suggest that the substituents present in the investigated hydrazone molecules have no significant influence on the derotonation processes. The changes in the absorbance $v s$. $\mathrm{pH}$ are used for determination of the acid dissociation constants at ionic strength of $0.1,0.25$ and $0.5 \mathrm{~mol} \mathrm{dm}^{-3}$. From these values the thermodynamic dissociation constants of hydrazones $\mathbf{H}_{1-}$ $\mathbf{H}_{4}$ are evaluated.

\section{REFERENCES}

[1] I. Suez, S. O. Pehkonen, M. R. Hoffman, Stability, Stoichiometry, and Structure of $\mathrm{Fe}(\mathrm{II})$ and $\mathrm{Fe}(\mathrm{III})$ Complexes with Di-2-pyridil Ketone Benzoylhydrazone: Environmental Applications, Environ. Sci. Technol., 28 2080-2086 (1994).

[2] L. H. Terra, A. M. C. Areias, I. Gaubeur, M. E. V. Suez-Iha, Solvent ExtractionSpectrophotometric Determination of Nickel(II) in Natural Waters Using DI-2Pyridyl Ketone Benzoylhydrazone, Spectroscopy Letters, 32(2) 257-271 (1999).

[3] P. G. Chowdary, K. M. Reddy, V. K. Reddy, P. R. Reddy, 2-Hydroxy-1naphthaldehyde-p-hydroxybenzoic hydrazone as a spectrophotometric reagent for the determination of lanthanium (III), Indian J Chem., 47 A 1381-1383 (2008).

[4] I. Warad, M. Abu-Eid, B. Sharydeh, Kinetics an mechanism of oxidation of L-cysteine by ferozineiron(III) complex in aqueous acidic medium, J. Saudi Chem. Soc., 10(2) 271-284 (2006).

[5] M. Mohan, M. P. Gupta, L. Chandra, N. K. Jna, Synthesis, characterization and antitumor properties of some metal (II) complexes of 2-pyridinecarboxaldehyde 2'pyridilhydrazone and related compounds, Inorg. Chim. Acta, 151 61-68 (1988).

[6] A. Sharifi, M. S. Abaee, M. Mirzaei, V. Abedi, Solvent-free solid-supported recovery of carbonyl compounds from $\mathrm{N}, \mathrm{N}$-dimethylhydrazones under microwave irradiation, ARKIVOC xv 17-21 (2006).

[7] J. Mokhtari, M. R. Naimi-Jamal, H. Hamzehali, Quantitative Regeneration of Carbonyl Compounds from Oximes and Hydrazones by Gaseous Nitrogen 
Dioxide, 11th International Electronic Conference on Synthetic Organic Chemistry (ECSOC-11) 1-30 November (2007).

[8] P. Sienkiewich, K. Bielawski, A. Bielawska, J. Palka, Inhibition of collagen and DNA biosynthesis by a novel amidine analogue of chlorambucil is accompanied by deregulation of $\beta 1$-integrin and IGF-I receptor signalong in MDA-MB 231 cells, Environ. Toxicol. Pharmacol., 20 118-124 (2005).

[9] L. K. Gupta, U. Bansal, S. Chandra, Spectroscopic approach in the characterization of the copper(II) complexes if isatin-3,2'-quinolyl-hydrazones and their adducts, Spectrochim. Acta A., 65 463-466 (2006).

[10] B. Kebede, N. Retta, V. J. Raju Y. Chebude, Synthesis and Characterization of 2,4,6-tris(hydrazino)-s-triazine and its Metal Complexes, Tran. Met. Chem., 31 (1) 19-26 (2006).

[11] H. Y. Lee, X. Song, H. Park, M. Baic, D. Lee, Torsionally Responsive $C_{3}-$ Symmetric Azo Dyes: Azo-Hydrazone Tautomerism, Conformational Switching, and Application for Chemical Sensing, J. Am. Chem. Soc., 132 (34) 12133-12144 (2010).

[12] S. Rollas, Ş. G. Küçükgüzel, Biological Activities of Hydrazone Derivatives, Molecules 12 1910-1939 (2007).

[13] M. Al-Nuri, A. Haroun, I. Warad, R. M. Mahfouz, A. Al-Resayes, M. Ali-Shtayeh, Synthesis and characterization of some antifungal active hydrazones from combined of several functionalized hydrazides with di-2-pyridil ketone, J. Saudi Chem. Soc., 11 (2) 313-318 (2007).

[14] K. Metwally, M. Abdel-Azis, M. Lashine, I. Husseiny, H. Badawy, Hydrazones of 2-aryl-quinoline-4-carboxylic acid hydrazides: Synthesis and preliminary evaluation as antimicrobial agents, Bioorg. Med. Chem., 14 (24) 8675-8682 (2006).

[15] S. Sirdhar, M. Saravanan, A. Rauesh, Synthesis and antibacterial screening of hydrazones, Schiff and Mannich bases of isation derivatives, Eur. J. Med. Chem., 36(7-8) 615-625 (2001).

[16] B. Zakir, C. Dağ, E. Yıldırım, K. Erol, M. F. Şahin, Synthesis and anticonvulsant activity of some hydrazones of 2-[(3H)-oxobenzoxazolin-3-yl-aceto]hydrazide, $J$. Fac. Pharm. Gazi., 18 99-106 (2001).

[17] N. Ergenz, N. S. Günay, Synthesis and antidepressant evaluation of new 3-phenyl5-sulfonamidoindole derivatives, Eur. J. Med. Chem., 33 143-148 (1998).

[18] U. Salgın-Gckşen, N. Gckhan-Kelekzi, C. Gcktaş, Y. Kcysal, E. Kılız, Ş. Işık, G. Aktay, M. Czalp, 1-Acylthiosemicarbazides, 1,2,4-triazole-5(4H)-thiones, 1,3,4thiadiazoles and hydrazones containing 5-methyl-2-benzoxazolinones: Synthesis, analgesic, antiinflammatory and antimicrobial activities, Bioorg. Med. Chem., 15 5738-5751 (2007). 
[19] N. Terzioğlu, A. Gbrsoy, Synthesis and anticancer evaluation of some new hydrazone derivatives of 2,6-dimethylimidazo[2,1-b]-[1,3,4]thiadiazole-5-carbo-hydrazide, Eur. J. Med. Chem., 38 633-643 (2003).

[20] A. S. Shawali, M. A. Aboutabl, H. M. Fahwy, A. Mazzah, E. Y. Osei-Twum, N. M. Abbas, Chelate formation of hydrazones, Transition Met. Chem., 17 517-520 (1992).

[21] R. B. Sinh, P. Jain, Hydrazones as analytical reagents: a review, Talanta (Great Britan) 29 77-84 (1982).

[22] M. Jankulovska, I. Spirevska, V. Dimova, A UV study of the behavior of some benzaldehyde hydrazones in acid medium, J Iran. Chem. Soc., 8 (2), 502-512 (2011).

[23] D. Kara, M. Alkan, Determination of acidity constants of acid-base indicators by second-derivative spectrophotometry, Spectrochim. Acta Part A 56 (14) 27532761 (2000).

[24] R. F. Cookson, The determination of acidity constants, Chem. Res. 1, 74 (1974)

[25] C. T. Davis, T. A. Geissman, Basic Dissociation Constants of Some Substituted Flavones, J. Am. Chem. Soc., 76 3507-3511 (1954).

[26] M. J. S. Dewar, E. G. Zoebisch, E. F. Healy, J. J. P. Stewart, Development and use of quantum mechanical molecular models. 76. AM1: a new general purpose quantum mechanical molecular model, J Am. Chem. Soc., 107 (13) 3902-3903 (1985)

[27] N. U. Perisić-Janjić, M. Lazarević, J. Janjić, Lj. Klisareva, Electronic spectra and ionization constants of N1-Salicylaldehyde-4-Hydroxybenzoylhydrazone, $U$. Scientist Phyl. Sciences 7 (1) 64-68 (1995).

Р ез и м е

\section{ОПРЕДЕЛУВАЊЕ НА КОНСТАНТИТЕ НА ДИСОЦИЈАЦИЈА НА НЕКОИ $p$-СУПСТИТУИРАНИ АРОМАТИЧНИ ХИДРАЗОНИ}

Киселинско-базното однесување на 5 p-супституирани ароматични хидразони е испитано со примена на UV спектрофотометрискиот метод. Влијанието на киселоста на средината врз апсорпционите спектри е следено во водни раствори од натриум хидроксид во $\mathrm{pH}$ подрачје од 7 до 14. Мерењата се направени на собна температура, додека вредноста на јонската сила изнесува $0,1,0,25$ и $0,5 \mathrm{~mol} \mathrm{dm}^{-3}$. Забележано е батохромно поместување на апсорпционата лента во базна средина, при рН вредност поголема од 7. Тоа покажува дека се одвива процес на дисоцијација на амидната и хидроксилната група. Енталпиите на депротонирање и вредностите на вкупната енергија се пресметани со примена на семиемпириските методи АМ1 и РМ3. 
Промените во UV спектрите со промена на $\mathrm{pH}$ на растворот се искористени за определување на константите на дисоцијација, $\mathrm{p} K_{\mathrm{BH}}$, при три различни вредности на јонската сила, како и термодинамичките константи на дисоцијација, при јонска сила нула. Пресметките се направени од вредностите на апсорбанцата на четири избрани бранови должини, од експерименталните и реконструираните спектри со карактеристична вектор анализа (CVA). Графичките $\mathrm{p} K_{\mathrm{BH}}$ вредности се добиени со линеарна регресиона анализа.

Клучни зборови: $p$-супституирани ароматични хидразони, UV спектрофотометрија, константи на дисоцијација, термодинамички константи на дисоциација, семиемпириски методи АМ1 и РМ3

Adress:

\section{Mirjana Jankulovska}

Ss. Cyril and Methodius University in Skopje

Faculty of Natural Sciences and Mathematics Institute of Chemistry,

Arhimedova 5, POBox 162, MK-1001 Skopje

Republic of Macedonia

jankulovska_m@yahoo.com

\section{Ilinka Spirevska}

Ss. Cyril and Methodius University in Skopje

Faculty of Natural Sciences and Mathematics Institute of Chemistry,

Arhimedova 5, PO Box 162, MK-1001 Skopje

Republic of Macedonia

ilinkas@iunona.pmf.ukim.edu.mk

\section{Katica Cholančeska Ragjenovikj}

Ss. Cyril and Methodius University in Skopje

Faculty of Technology and Metallurgy

PO Box 580, MK-1001 Skopje

Republic of Macedonia

kcoli@yahoo.com 